\title{
W kierunku normalizacii wyników badań o handlu detalicznym. Próba reklasyfikacii działalności handlowej
}

\section{Retail Reclassification as an Important Step in Normalisation Process in Retail Studies}

Streszczenie: Artykuł dotyczy ważnego problemu pozyskiwania danych o handlu detalicznym oraz możliwości porównywania wyników badań realizowanych w oparciu o inwentaryzację terenową. Problem wynika z zaobserwowanej przez autorkę ogromnej dywersyfikacji typologizacji działalności handlowej w badaniach naukowych oraz braku jednoznacznych definicji pojęć: sklep, punkt handlowy i innych, jakimi posługują się badacze w procesie inwentaryzacji. Cel pracy jest następujący: autorka, w oparciu o liczne inwentaryzacje ( $\mathrm{z}$ różnych okresów) dokonała alternatywnej wobec PKD typologizacji handlu detalicznego. Istotą prezentowanej typologii jest możliwość poszerzania i pogłębiania wielopoziomowej typologii handlu, w zależności od potrzeb badacza. Wielopoziomowość umożliwia odpowiedzi na różny zakres pytań naukowych - od branżowości punktu sprzedaży po określenie jego struktury funkcjonowania (dyskont, galeria handlowa itd.). Równocześnie podkreśla się, że typologia nie jest zamknięta w obrębie stacjonarnych form handlu. W tekście omówiono metody pozyskiwania danych w zakresie handlu detalicznego, ze szczególnym uwzględnieniem metod inwentaryzacyjnych. Kolejno przeprowadzono analizę poziomu zgodności pomiędzy publicznymi danymi statystycznymi a wynikami autorskiej inwentaryzacji terenowej na przykładzie trzech miast różnej skali: Nysy, Bielska-Białej i Wrocławia. W oparciu o zebrane surowe dane statystyczne dokonano typologizacji działalności handlu detalicznego - jako kroku w dążeniu do ujednolicenia badań inwentaryzacyjnych.

\begin{abstract}
The article focuses on an important problem of retail data sources and ability to make inventory databases comparable. The biggest problem with the inventory methods lay in difficulties to compare the results from different research. This fact has resulted from: existence of only one widely known, not fully corresponding to reality retail classification (public PKD) (1), diversified typology of the retail structure created by each researcher for their own purpose (2), and the lack of unambiguous definitions of such terms as a retail point, a shop etc. (3). The aim of the article is to establish an alternative to the PKD retail typology, based on the author's experience from many inventories. The essence of this topology lies in an ability to broaden and deepen the presented structure on the basis of the individual researcher's needs. Five-level structure of the typology shows answers to the different types of questions, not only about the branches but about the retail point types (discount, shopping mall etc.) among others. Simultaneously, the typology is still open and can be modified. In the text, there are discussed retail data sources with the biggest emphasis on the inventory
\end{abstract}


method. Next, there are presented analysis of the compliance level between public statistical data and the results from own inventory of 3 case studies: Nysa, Bielsko-Biała, and Wrocław. The raw statistical data of those cities were directly used to build the retail typology presented in the article.

Słowa kluczowe: handel detaliczny; inwentaryzacja; klasyfikacja; PKD; reklasyfikacja; typologia handlu Keywords: classification; reclassification; retailing; retail inventory; typology of the retail

Otrzymano: 18 grudnia 2017

Received: 18 December 2017

Zaakceptowano: 13 maja 2018

Accepted: 13 May 2018

Sugerowana cytacja / Suggested citation:

Mayer-Wydra, M. (2018). W kierunku normalizacji wyników badań o handlu detalicznym. Próba reklasyfikacji działalności handlowej. Prace Komisji Geografii Przemysłu Polskiego Towarzystwa Geograficznego, 32(2), 255-277. https://doi.org/10.24917/20801653.322.18

\section{WSTĘP}

Dynamiczna tendencja przeobrażeń struktur sprzedaży detalicznej jest dziś faktem powszechnym, a wręcz globalnym. To, co obserwowali B.J.L. Berry (1967) oraz P.T. Kivell i G. Shaw (1980) w krajach Zachodu jeszcze w latach sześćdziesiątych i siedemdziesiątych XX wieku, dziś wydaje się procesem niemal nieodwracalnym, trudnym do zatrzymania czy choćby spowolnienia w innych częściach świata. Pod wpływem międzynarodowych marek lokalne rynki handlu ulegają coraz silniejszym przekształceniom. Procesy te odzwierciedlają rosnący potencjał struktury handlowej i procesów w obrębie wewnętrznego rynku wymiany towarów jako istotnych mierników poziomu życia społeczno-gospodarczego $\mathrm{w}$ różnych skalach. Weryfikacja tych przeobrażeń wymaga coraz szerszych, a przede wszystkim aktualnych baz danych. 0 ile pewną grupę takich danych z powodzeniem zdobywają i przetwarzają wyspecjalizowane firmy, o tyle podmioty statystyki publicznej oraz je wykorzystujący pozostają z niezwykle okrojonymi i błędnymi bazami danych o tej dziedzinie gospodarki. Fakt ten jest podkreślany w licznych publikacjach, niezależnie od okresu prowadzonych badań czy wykorzystywanych źródeł (Chudzyńska, 1985; Nowosielska, 2000; Celińska-Janowicz, 2016).

W konsekwencji można mówić o dwubiegunowym charakterze źródeł danych, na których opierają się badania naukowe: gotowe bazy danych - publiczne i komercyjne (najpopularniejsze) oraz dane autorskie, pozyskiwane z inwentaryzacji terenowych (przede wszystkim w skali małych miast lub wewnętrznych fragmentów jednostek osadniczych, dotyczące głównie badań z pogranicza geografii i urbanistyki). Istnieją również przesłanki w zakresie możliwości wykorzystywania pewnych alternatywnych źródeł, takich jak książki telefoniczne.

Niniejszy artykuł przedstawia metody pozyskiwania danych w zakresie handlu detalicznego, ze szczególnym uwzględnieniem metod inwentaryzacyjnych. W dalszej części autorka przeprowadza analizę poziomu zgodności pomiędzy publicznymi danymi statystycznymi a wynikami autorskiej inwentaryzacji terenowej na przykładzie trzech miast różnej skali: Nysy, Bielska-Białej i Wrocławia. W oparciu o zebrane surowe dane statystyczne dokonano typologizacji działalności handlu detalicznego jako ważnego etapu w dążeniu do ujednolicenia badań inwentaryzacyjnych. 


\section{ŹRÓDŁA DANYCH O HANDLU DETALICZNYM}

Informatyzacja systemów obsługi w handlu umożliwiła znaczny przeskok w zakresie pozyskiwania danych statystycznych o poziomach sprzedaży, charakterystyce klientów czy też o zmianach generowanego popytu (w oparciu o kody kreskowe, karty stałego klienta, realizacje płatności kartą debetową). W wyniku tego powstają gigantyczne bazy danych, dostępne jednak przede wszystkim w obiegu komercyjnym. Jednymi z najpopularniejszych takich źródeł danych są bazy: Retail Index, Euromonitor International. Choć ich zawartość jest nie do przecenienia dla badaczy handlu i działalności gospodarczej, to jednak ogromną barierę w ich pozyskiwaniu stanowi cena za dostęp.

Firmy analityczne, takie jak Deloitte czy PwC, działają również na polu open access, jednak wyłącznie w zakresie raportów zbiorczych, których poziom przydatności dla badań naukowych jest porównywalny z innymi publikacjami popularnonaukowymi i prasowymi (m.in. z powodu braku przedstawionej metodologii badań). Zwraca się tu uwagę na ograniczoną możliwość weryfikacji wniosków oraz porównywania danych pomiędzy różnymi źródłami, które cechuje ogromna dywersyfikacja metod pozyskiwania i przetwarzania danych pierwotnych (Kucharska, Malinowska, 2016). Co więcej, bazy tego typu funkcjonują w Polsce stosunkowo od niedawna, co wciąż jeszcze ogranicza możliwości ich wykorzystania.

Powszechnie dostępnymi źródłami informacji o działalności gospodarczej, w tym sprzedaży handlu detalicznego, są: Organisation for Economic Cooperation and Development (OECD, dot. skali globalnej), Eurostat (w skali Unii Europejskiej), a w przypadku Polski - Krajowy Rejestr Urzędowy Podmiotów Gospodarki Narodowej (REGON) oraz Centralna Ewidencja i Informacja o Działalności Gospodarczej (CEIDG), na których opierają się m.in. publikowane dane Głównego Urzędu Statystycznego (GUS).

Mimo powszechnego wykorzystania tych źródeł w badaniach naukowych, wielokrotnie zwracano uwagę na ich nadreprezentacyjność oraz nieaktualność, co de facto oznacza tworzenie błędnych lub niepełnych wniosków badawczych (Rowley, 1984; Raczyk, 2009). O ile stan ten jest do zaakceptowania w pewnych przypadkach, w tym porównywania wyłącznie danych GUS, a więc obarczonych podobną podstawą nadmiaru jednostek obserwacji (co jednak nigdy nie zostało udowodnione), o tyle odniesienie ich do różnych źródeł danych i szerszej perspektywy czasowej jest już wysoce wątpliwe co do poprawności uzyskanych wyników.

Błędy zawarte w rejestrach statystycznych wynikają wprost z procesu zgłaszania działalności przez podmioty do urzędu. W pierwszej kolejności należy wymienić konieczność zakwalifikowania działalności do jednej z podkategorii klasyfikacji działalności gospodarczej. Szczególnie w tym względzie daleka od ideału pozostaje klasyfikacja działalności handlowej. W rzeczywistości struktura sklepów nieustannie ewoluuje pod względem szerokości, głębokości oferowanego asortymentu i sposobu sprzedaży. Z tego powodu również zgłaszający swą działalność handlową często kwalifikują ją do różnych podkategorii (co w prosty sposób można zweryfikować w wyszukiwarce CEIDG). W konsekwencji następuje rozmycie informacji statystycznej o nowych i trudnych do sklasyfikowania typach działalności handlowej.

Kolejną kwestią pozostaje liczba dominujących branż, jakie prowadzący działalność zgłasza do urzędu. Ze względów praktycznych przyjęło się zawyżanie ich liczby do wszystkich potencjalnych branż, w obrębie których może działać przedsiębiorca. W ten sposób podmiot zabezpiecza się na wypadek poszerzenia lub zmiany profilu 
działalności, przy jednoczesnym braku konieczności zgłaszania tego faktu do urzędu. Rezultat jest taki, że dane REGON mają nadreprezentatywność pewnych form sprzedaży, w tym w szczególności następujących: sprzedaż detaliczna prowadzona w niewyspecjalizowanych sklepach z przewagą żywności, napojów i wyrobów tytoniowych (47.11.Z), sprzedaż detaliczna wyrobów tytoniowych prowadzona w wyspecjalizowanych sklepach (47.26.Z), sprzedaż detaliczna kosmetyków i artykułów toaletowych prowadzona w wyspecjalizowanych sklepach (47.75.Z).

Należy również zwrócić uwagę na wielkopowierzchniowe obiekty handlowe, skupiające podmioty handlowe. W PKD 2007 istnieją dwie kategorie odpowiadające tego typu obiektom: 47.11.Z1 oraz 47.19.Z². Szczególnie w oparciu o kontekst domów towarowych (47.19.Z) można zauważyć pewną komplikację. Inaczej niż kiedyś, aktualnie domy handlowe nie funkcjonują w oparciu o jeden podmiot gospodarczy (np. DH Feniks, Wrocław).

Kolejnym argumentem, przemawiającym za niemożnością wykorzystania do wielu badań urzędowych danych statystycznych, jest ich błędna grupa cech przestrzennych. O ile dane ogólnodostępne GUS takich informacji nie mają w ogóle, o tyle na poziomie pozyskiwania danych REGON oraz z urzędów lokalnych metadane mogą okazać się tylko częściowo odzwierciedlające stan rzeczywisty. Wynika to z faktu, że podmiot zakładający działalność gospodarczą zgłasza „adresy siedziby bądź miejsca zamieszkania w przypadku osoby fizycznej będącej przedsiębiorcą" (Jak uzyskać wpis..., 2017), co często nie jest jednoznaczne z miejscem prowadzenia działalności gospodarczej, szczególnie w przypadku posiadania przez firmę więcej niż jednej placówki handlowej. Okazuje się, że reprezentatywność danych urzędowych może być też zróżnicowana pod względem lokalizacji wewnątrz jednostki osadniczej. Jak wynika z badań A. Raczyka (2009: 143), zdecydowana nadreprezentacja jednostek nieistniejących oraz o nieustalonym statusie występuje w obszarach peryferyjnych. Stąd wniosek, że interpretacja bazy REGON nie daje jednoznacznych wyników na temat rzeczywistego stanu przestrzeni.

Szczególnie więc przy analizach rozmieszczenia przestrzennego handlu to inwentaryzacja terenowa okazuje się najbardziej wiarygodną, choć jednocześnie najbardziej pracochłonną formą pozyskiwania danych. 0 ile wskazuje się na pewne trudności w utworzeniu kompletnej bazy na podstawie inwentaryzacji szeroko pojętych usług, o tyle nie powinno dotyczyć to samych usług handlu detalicznego. W przeciwieństwie bowiem do tzw. ukrytych form działalności gospodarczej (m.in. biur rachunkowych, pracowni krawieckich), handel detaliczny charakteryzuje się potrzebą „pokazania się” w przestrzeni, informowania o swej lokalizacji potencjalnych klientów, których część wciąż stanowią przechodnie. Chociaż nie wyklucza się możliwości pojawienia się właśnie ukrytych obiektów handlowych w przestrzeni, w tym opartych na reklamie internetowej, to z punktu widzenia niniejszych badań wciąż jeszcze można uznać je za marginalne.

Wobec licznych badań naukowych wykorzystujących ten sposób pozyskiwania danych, zwraca się uwagę jedynie na brak ich regularności oraz fragmentaryczność. Dążąc do zawężenia skali badań, ograniczenia dokonuje się przede wszystkim na płaszczyźnie przestrzeni (w granicach administracyjnych mniejszych miast: Taylor, 2000; Twardzik, 2009) lub wewnętrznych fragmentów jednostek osadniczych (Płaziak, Szymańska,

\footnotetext{
1 Sprzedaż detaliczna prowadzona w niewyspecjalizowanych sklepach z przewagą żywności, napojów i wyrobów tytoniowych.

2 Sprzedaż detaliczna prowadzona w niewyspecjalizowanych sklepach, gdzie żywność, napoje i wyroby tytoniowe nie zajmują dominującej pozycji; do tej kategorii zalicza się działalność domów towarowych.
} 
2016; Twardzik, Halama, 2017), struktury branżowej (stacje paliw: Miszewska, Slenczyk, 1998; targowiska: Wojdacki, 2011; inne: Maleszyk, 2008) lub formy sprzedaży (najpopularniejsze we współczesnych badaniach Europy Środkowo-Wschodniej, dot. dyskontów, centrów handlowych lub podobnych: Maleszyk, 1999; Werwicki, 2000; Zipser, 2004).

Tym niemniej należy wspomnieć o obecności w literaturze analiz całościowych obszarów wielkoskalowych, w tym m.in. dla Wrocławia, Poznania i Bolesławca (Pustelnik, 1979), Bielska-Białej (Pustelnik, 1979; Zallam, 1993), województwa wrocławskiego i rejonów podgórskich (Zipser, 1977; 1979). Badania te - przy wysokim stopniu szczegółowości opisu metody agregacji danych pierwotnych - można uznać za istotne w szczegółowych badaniach zmienności struktury handlu detalicznego. Brak odniesienia do tego typu źródeł archiwalnych. Zauważa się jednak pewne ograniczenie możliwości wykorzystania wyników tych badań, polegające na konstruowaniu jednopoziomowej klasyfikacji działalności handlowej, co uniemożliwia czasem porównanie z późniejszymi modyfikacjami pewnych grup branż (np. w latach siedemdziesiątych sklepy odzieżowe rozróżniano przede wszystkim ze względu na: męskie - damskie młodzieżowe - dziecięce, dziś nastąpiła konsolidacja tych grup na rzecz rozwarstwienia w innym kierunku, np. markowe - niemarkowe - outlety - tania odzież).

Omówienie procesu inwentaryzacji wymaga komentarza wobec współczesnych możliwości jej przeprowadzania. Poza tradycyjną formą ewidencji prowadzonej w terenie, dostępne są narzędzia analizy przestrzeni poprzez obraz wirtualny, w tym aplikację Google Street View. Forma ta jest przez część naukowców krytykowana za brak pełnej dostępności przestrzeni oraz często zdywersyfikowane okresy pozyskiwania obrazów (w tym z różnych lat). Istotnie ścieżki street view nie pokrywają w sposób kompletny struktur osadniczych (szczególnie w Niemczech, Austrii oraz w krajach zza wschodniej granicy Polski), niemniej obejmują najważniejsze przestrzenie, w tym znaczą część ciągów komunikacyjnych w największych miastach Polski. Ponadto są rzetelnie datowane, co w przypadku niektórych miast zachodnich umożliwia już w chwili obecnej analizę retrospektywną całej struktury zagospodarowania poszczególnych ciągów komunikacyjnych (nie tylko ulic). Problemem wydaje się brak możliwości weryfikacji wnętrza sklepu, chociaż i na tym polu obserwuje się już pewne rozwiązania: niektóre obiekty, w tym galerie i centra handlowe, udostępniają możliwość „przechadzania się" po swych wnętrzach poprzez aplikację street view, normą zaś większości wielobranżowych struktur handlowych (od centrów handlowych po hale targowe i bazary włącznie) jest posiadanie własnej strony internetowej z aktualnymi planami rozmieszczenia punktów sprzedaży.

Aplikacja typu street view stanowi ogromny potencjał i ułatwienie w obszarze szczegółowych analiz przestrzennych, choć na chwilę obecną może dotyczyć przede wszystkim wybranych fragmentów przestrzeni.

Istnieje również trzecia metoda, stworzona i udowodniona w zakresie swej rzetelności przez M. Palomäkiego (1964). Jego badania w zakresie handlu detalicznego w południowej Bothnii (Finlandia) były prowadzone, poza inwentaryzacją terenową, w oparciu o dane pochodzące z książek telefonicznych. Baza ta okazała się niezwykle cennym źródłem danych w dobie powszechnie występujących telefonów stacjonarnych, w tym u niemalże każdego przedsiębiorcy. Trzeba wspomnieć, że o ile nie zawsze numer telefonu odpowiadał punktowi adresowemu, w którym aparat się znajdował, o tyle istotny był przede wszystkim adres sklepu, który stanowił informację o jego lokalizacji, 
a nie np. miejscu zamieszkania jego właściciela. Fakt ten wynikał z traktowania w tych czasach książek telefonicznych jako dobrego źródła reklamy.

Podobna tendencja miała miejsce w Polsce dopiero od połowy lat dziewięćdziesiątych XX wieku, co wynikało przede wszystkim z upowszechnienia się telefonów stacjonarnych, a przez długi czas również zależności funkcjonowania łączy internetowych od sieci telefonii stacjonarnej. W oparciu o analogię dyfuzji innowacji (telefonów stacjonarnych i książek telefonicznych jako skutecznej reklamy) można stwierdzić, że książki telefoniczne z drugiej połowy lat dziewięćdziesiątych stanowią dobre źródło pozyskiwania danych archiwalnych na temat handlu detalicznego w Polsce.

Górną granicą rzetelności źródła jest rok 2004, w którym weszło w życie prawo telekomunikacyjne. Art. 169 ust. 3 informuje o możliwości zamieszczania w spisie danych identyfikujących abonenta będącego osobą fizyczną wyłącznie w oparciu o wyrażenie przez niego zgody na dokonanie tych czynności. W konsekwencji tego zapisu spis abonentów w książkach telefonicznych musiał być zredukowany o osoby fizyczne niewyrażające takiej zgody. Równolegle należy pamiętać, że osoby prowadzące działalność gospodarczą to nie tylko osoby prawne, ale również osoby fizyczne (osoba fizyczna wykonująca działalność gospodarczą, wpisana do rejestru CEIDG). Poza aspektami prawnymi, za istotne należy uznać zmiany rynkowe i technologiczne, w tym przejmowanie krajowego rynku telekomunikacji przez sieci komórkowe, które notowały intensywny rozwój już od 1999 roku (Zieliński, 2017), przy równoległej stałej tendencji spadkowej posiadaczy telefonów stacjonarnych (szczególnie w miastach). Skończył się również monopol TP SA na obsługę sieci stacjonarnych (pojawiły się m.in. UPC, Netia, Orange). Wszystkie powyższe czynniki przyczyniły się do obniżenia potencjału książek telefonicznych jako kompletnej bazy danych.

\section{OPTYMALIZACJA ŹRÓDEŁ DANYCH DO BUDOWANIA MACIERZY DANYCH O HANDLU}

Tab. 1 stanowi podsumowanie wyżej omówionych metod pozyskiwania danych typu open access w zakresie handlu detalicznego.

Tab. 1. Porównanie źródeł danych o charakterze open access dot. handlu detalicznego w Polsce (rangowanie w skali $<-1 ; 1>$ )

\begin{tabular}{|c|c|c|c|}
\hline & [1] & {$[2]$} & {$[3]$} \\
\hline & REGON & Inwentaryzacja & Książka telefoniczna \\
\hline Szybkość pozyskania danych & 1 & -1 & 0 \\
\hline Stopień dokładności & -1 & 1 & 0 \\
\hline \multirow{2}{*}{$\begin{array}{l}\text { Szerokość możliwych do } \\
\text { pozyskania cech danych }\end{array}$} & -1 & 1 & 0 \\
\hline & narzucona & dowolna & ograniczona \\
\hline Możliwość analizy przestrzennej & -1 & 1 & 1 \\
\hline Możliwości porównania & 1 & $0^{*}$ & 0 \\
\hline \multirow[b]{2}{*}{ Aktualność danych } & 0 & 1 & -1 \\
\hline & $\begin{array}{c}\text { dane archiwalne } \\
\text { z rocznym } \\
\text { opóźnieniem }\end{array}$ & $\begin{array}{c}\text { w okresie } \\
\text { prowadzenia badań }\end{array}$ & $\begin{array}{c}\text { tylko dla lat } \\
\text { dziewięćdziesiątych } \\
\text { XX wieku }\end{array}$ \\
\hline SUMA & -1 & 3 & 0 \\
\hline
\end{tabular}

* Zależy od szczegółowości opisu metody badawczej.

Źródło: opracowanie własne 
Bilans ten uznaje metodę inwentaryzacyjną za najlepszą z punktu widzenia analizowanych czynników. W rzeczywistości zalety korzystania ze źródeł [2] i [3] niwelowane są przez czasochłonność ich pozyskiwania oraz trudności komparacji.

Ponadto trzeba mieć na uwadze, że obecne zmiany w sektorze sposobu sprzedaży generują tak odmienne warunki, iż już wkrótce sama inwentaryzacja jako sposób zbierania danych może okazać się niewystarczająca (analogicznie do obecnego potencjału książek telefonicznych). Dotyczy to przede wszystkim procesu powszechnej informatyzacji usług przestrzennych i upowszechniania sprzedaży internetowej. W przestrzeni wirtualnej tworzona jest baza danych przestrzeni realnej (Google Maps, OpenStreetMap, Panorama Firm i inne), która zmienia wagę czynników lokalizacji w procesie doboru umiejscowienia działalności gospodarczej. Warto jednak podkreślić, że występowanie obiektów w tych bazach ma charakter dobrowolny i nie jest w żaden sposób regulowane (w przypadku map Google występuje wiele błędów z powodu powszechnego dostępu do treści mapy, dokładniejsze mapy OpenStreetMap są natomiast wciąż jeszcze niekompletne). Z drugiej strony zaś mamy do czynienia z „zasysaniem” przestrzeni rzeczywistej przez internet (sklepy funkcjonujące wyłącznie w przestrzeni wirtualnej) i upowszechnianiem się możliwości sprzedaży przez osoby fizyczne nieprowadzące działalności gospodarczej (poprzez portale takie jak: Allegro.pl., Olx.pl, Sprzedajemy.pl, Gumtree.pl i inne). Jakkolwiek trudna do weryfikacji jest struktura handlu detalicznego na płaszczyźnie wirtualnej (wciąż jeszcze), to jednak przewiduje się systematyczny wzrost jej istotności z punktu stanowienia silnej konkurencji wobec handlu stacjonarnego.

\section{DANE STATYSTYCZNE A RZECZYWISTE - ANALIZA POZIOMU ZGODNOŚCI}

Skala błędów statystyki publicznej była już wykazywana przez wielu badaczy. Niemniej jednak warto raz jeszcze zwrócić uwagę na różnice, jakie wykazały badania terenowe autorki względem danych publikowanych przez GUS, w tym dotąd nieanalizowanego poziomu zróżnicowania skali błędu.

Dla zachowania poprawności interpretacyjnej zwraca się uwagę na znaczenie stosowanych pojęć. Odwołując się do publikacji GUS w tym zakresie, wskazuje się, że punkty handlu tymczasowego stanowią tu łącznie wszystkie stragany uliczne i kioski (jako formę architektoniczną nieprzytwierdzoną na stałe do gruntu). Warto jednak zauważyć, że stragany oddziałują w znacznie odmienny sposób na przestrzeń, chociażby ze względu na faktyczną możliwość przemieszczania się i brak stałych godzin funkcjonowania. Łączenie tych dwóch typów punktów sprzedaży wydaje się pewnym anachronizmem, odbiegającym od przydatności interpretacyjnych. Stąd zapewne powszechne stwierdzenie o malejącym udziale kiosków w strukturze przestrzennej. Okazuje się, że w strukturze szczegółowej ten podtyp branży (jako sklep wielobranżowy typu kiosk) zajmuje nawet trzecie miejsce $\mathrm{w}$ rankingu częstotliwości występowania (we Wrocławiu).

Podobnie domy towarowe i handlowe to formy handlu, które już powoli przechodzą do historii. Błędy pomiędzy statystyką GUS a stanem faktycznym wynikają m.in. z faktu występowania w przestrzeni wciąż jeszcze tych budynków i podmiotu zarządzającego. W konsekwencji mimo stopniowego pustoszenia budynków z funkcji handlowych lub ich transformacji w inne formy sprzedaży, dla urzędu wciąż pozostają formami stałymi (np. Dom Handlowy Podwale, Wrocław). Równocześnie urząd 
statystyczny traktuje łącznie hipermarkety, galerie i centra handlowe, supermarkety i dyskonty, co wynika raczej z ich powierzchni użytkowej niż ze struktury organizacji handlu, a w konsekwencji obniża zakres możliwości ich analizy sieciowej.

Poniżej (tab. 2-4) zestawiono dane o handlu zebrane na podstawie inwentaryzacji terenowych w latach 2014-2015 dla miast: Bielsko-Biała, Nysa, Wrocław. Dane te porównano z wynikami publikowanymi przez GUS, zachowując urzędowe definiowanie pojęć.

Tab. 2. Korelacja danych statystycznych GUS i rzeczywistych (z inwentaryzacji) dla Wrocławia, 2015

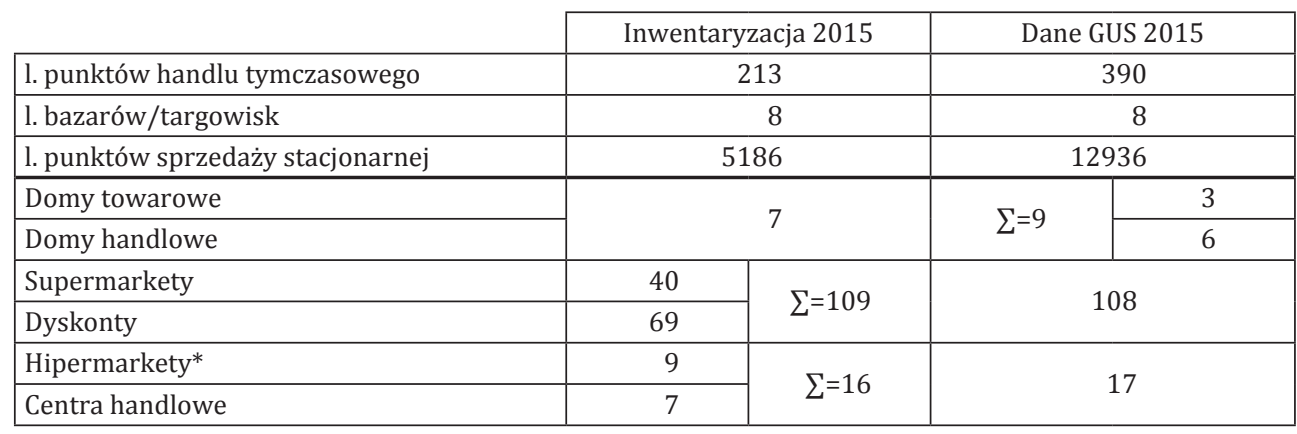

* Według klasyfikacji autorki: hipermarkety i galerie handlowe stanowią osobną kategorię, tu: traktowane łącznie w celach porównawczych z GUS; podobnie u autorki: centra handlowe zawierają w sobie hipermarkety i supermarkety.

Źródło: opracowanie własne na podstawie danych GUS (2015) oraz inwentaryzacji własnej

Tab. 3. Korelacja danych statystycznych GUS i rzeczywistych (z inwentaryzacji) dla Bielska-Białej, 2015

\begin{tabular}{|c|c|c|c|}
\hline & Inwen & 2015 & Dane GUS 2015 \\
\hline l. bazarów/targowisk & \multicolumn{2}{|c|}{6} & 7 \\
\hline l. punktów sprzedaży stacjonarnej & \multicolumn{2}{|c|}{1924} & 3368 \\
\hline Domy towarowe & \multirow{2}{*}{\multicolumn{2}{|c|}{0}} & 0 \\
\hline Domy handlowe & & & 1 \\
\hline Supermarkety & 36 & \multirow{2}{*}{$\sum=50$} & \multirow{2}{*}{41} \\
\hline Dyskonty & 14 & & \\
\hline Hipermarkety & 7 & \multirow{2}{*}{$\sum=9$} & \multirow{2}{*}{7} \\
\hline Centra handlowe & 2 & & \\
\hline
\end{tabular}

Źródło: opracowanie własne na podstawie danych GUS (2015) oraz inwentaryzacji własnej

Tab. 4. Korelacja danych statystycznych GUS i rzeczywistych (z inwentaryzacji) dla Nysy, 2015

\begin{tabular}{|c|c|c|c|}
\hline & Inwen & 2015 & Dane GUS 2015 \\
\hline l. bazarów/targowisk & & & 1 \\
\hline l. punktów sprzedaży stacjonarnej & & & 1278 \\
\hline Domy towarowe & \multirow{2}{*}{\multicolumn{2}{|c|}{0}} & 0 \\
\hline Domy handlowe & & & 0 \\
\hline Supermarkety & 3 & \multirow{2}{*}{$\sum=13$} & \multirow{2}{*}{13} \\
\hline Dyskonty & 10 & & \\
\hline Hipermarkety & 1 & \multirow{2}{*}{$\sum=1$} & \multirow{2}{*}{2} \\
\hline Centra handlowe & 0 & & \\
\hline
\end{tabular}

Źródło: opracowanie własne na podstawie danych GUS (2015) oraz inwentaryzacji własnej 
Zaobserwowane różnice w wynikach, szczególnie w zakresie obiektów wielkopowierzchniowych, wskazują na różnicę czasu przeprowadzania inwentaryzacji a okresem opublikowania danych przez GUS (np. zmiany w funkcjonowaniu kilku domów towarowych we Wrocławiu), ale częściej dotyczą zróżnicowanego klasyfikowania obiektów pewnych marek do działu: supermarkety lub hipermarkety. 0 ile badania nie podważają słuszności tych kwalifikacji, co z pewnością wynika z przyjętej w projekcie architektoniczno-budowlanym powierzchni użytkowej budynku, o tyle badaczy wprowadza to w błąd. Okazuje się bowiem, że np. w Nysie - według GUS - funkcjonują dwa hipermarkety, w tym zaliczany w pozostałych miastach do supermarketów, a co więcej tak się reklamujący Kaufland. Wiele podobnych dysproporcji pierwszej grupy sklepów zauważono również w Bielsku-Białej. Niemniej jednak najbardziej znacząca jest różnica w liczbie sklepów (przeszacowanie pomiędzy 1,75 a dwuipółkrotnością wobec stanu faktycznego). Tendencja ta rośnie wraz ze wzrostem skali miasta.

Wnioskować więc można, że dane GUS nie odzwierciedlają stanu rzeczywistego struktury handlu detalicznego, co dotyczy przede wszystkim punktów sprzedaży poza obiektami wielkopowierzchniowymi oraz bazarami. Wynika to zapewne z dynamiki zmian, jaka ma miejsce w tej grupie obiektów sprzedaży. Niemniej jednak intuicja badacza, a także obserwacja zjawisk rzeczywistych, pozwala sądzić, że nie mogą to być zmiany tak liczne (rzędu dwukrotnej różnicy stanu rzeczywistego wobec statystycznego).

\section{ZAMIAST PODSUMOWANIA: SYSTEMATYKA BRANŻ HANDLU DETALICZNEGO}

Skala błędów statystyki publicznej ponownie skłania do podejmowania badań w oparciu o inwentaryzacje, o ile to możliwe. Decydując się na wykorzystanie alternatywnych wobec oficjalnych źródeł danych, badacz musi liczyć się z koniecznością ich obróbki, przez co należy rozumieć agregację, typologię i standaryzację cech danych. Brak informacji o tym procesie w opracowaniach naukowych może utrudniać dalsze ich wykorzystanie.

W niniejszych badaniach zastosowano systematykę punktów sprzedaży handlu detalicznego w oparciu o rodzaj branży [2], szerokość [1] i głębokość oferty [3], przedstawioną w tab. 5 .

Jednym z podstawowych pytań wobec różnych źródeł danych jest to, w jaki sposób rozpatrywane są sklepy z kilkoma branżami dominującymi. Mając na uwadze rozkład przestrzenny występowania branż, podział na punkty jedno- i wielobranżowe może stanowić zbyt duże uogólnienie. Zatracić można w ten sposób informacje o wielu branżach, w tym np. chemii gospodarczej (często występującej w kooperacji z drogeriami, tanią odzieżą lub papierniczymi), piekarniach (łączonych często z cukierniami, sklepami monopolowymi lub żywnością ekologiczną), księgarniach czy sklepach papierniczych. W wielu badaniach, w tym T. Zipsera (1977; 1979) i R. Pustelnika (1979) są one traktowane jako osobna kategoria. Metoda nie jest jednak skuteczna, szczególnie ze względu na aktualną dywersyfikację oferty handlowej. Tylko w przestrzeni badanych miast można wskazać wiele przypadków unikatowych, takich jak: rowery + kominki (Nysa, rynek), części samochodowe + rowery (Bielsko-Biała, ul. Akademii Umiejętności), AGD + księgarnia (Wrocław, ul. Orzechowa). Potraktowanie każdego z nich osobno prowadzi do zwiększania liczby cech i tworzenia wielu zbiorów jednoelementowych, co jest błędne z punktu widzenia zasad poprawnej standaryzacji. 
Rozwiązanie tego problemu leży w podziale punktów handlowych na trzy kategorie ze względu na szerokość oferowanego asortymentu: jednobranżowe, dwu-trzybranżowe, wielobranżowe. Przekłada się to na obecność w macierzy danych trzech kolumn z informacją o rodzaju branży dla każdego elementu, przy czym pierwsza kolumna posiada informację dla wszystkich kategorii punktów, kolejne dwie są wypełnione w przypadku punktów dwu- i trzybranżowych.

Kolejnym problemem w procesie systematyzacji punktów handlowych jest określenie stopnia szczegółowości branż obiektów handlowych. Zwykle decyduje się na pewien stopień ogólności (np. PKD), ale w takich przypadkach nie jest możliwe wychwycenie informacji o pewnych grupach branż unikatowych (np.: filatelistyka, artykuły erotyczne) lub trudnych do jednoznacznej klasyfikacji. Dobrym przykładem może tu być wędkarstwo. Czy należy je traktować na tym samym poziomie szczegółowości co branżę zoologiczną lub sportową? A jeśli nie, to której z tych branż stanowi podkategorię? Według PKD 2007 jest to podkategoria artykułów sportowych (47.64.Z), jednak w rzeczywistości jest różnie rozpatrywana przez samych przedsiębiorców.

Problem ten jest znacznie szerszy i dotyczy liczby stopni szczegółowości. Mamy więc $\mathrm{w}$ przestrzeni miast do czynienia z ogromną liczbą sklepów branży ogólnospożywczej (typ branży), ale i takich, które oferują tylko produkty wyspecjalizowane: mięsne, mleczarskie, monopolowe (podtypy branży). W przypadku sklepów monopolowych, szczególnie w ciągu ostatnich lat, rozwinęły się ich specjalizacje (rodzaje): sklepy winiarskie i piwne. Analogiczny problem określenia szczegółowości oferty handlowej dostrzega się praktycznie we wszystkich branżach.

Stąd zdecydowano się stworzyć typologię działalności gospodarczej o charakterze handlu detalicznego. Różnica względem PKD polega przede wszystkim na wielostopniowości i jednoznaczności, ponieważ zawiera wszystkie jednostkowe nazwy zaobserwowane podczas inwentaryzacji.

Ryc. 1. Schemat typologii branż handlu detalicznego

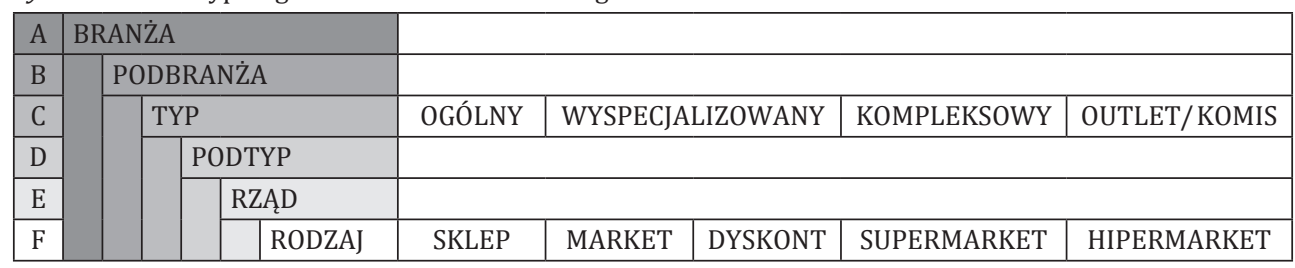

Źródło: opracowanie własne

W takim układzie wyróżniono: 19 branż oraz 46 podbranż, z których większość dzieli się na typy (z podziałem na sklep z asortymentem ogólnym, wyspecjalizowanym, kompleksowym oraz tzw. outlet, w tym komisy i sklepy z elementami używanymi). Pełen spis zawiera 350 rodzajów branż, przy czym należy pamiętać, że wyczerpuje on jedynie zakres aktualny (z lat 2012-2018) inwentaryzowanych terenów (Bielsko-Biała, Częstochowa, Nysa, Radom, Wrocław).

Zawarta w niniejszej publikacji typologia daje naukowcom możliwość jednoznacznego odniesienia się do poziomu badanych jednostek. Równocześnie rozpowszechnienie tej systematyki nadaje wynikom inwentaryzacji cech komparatywności i jednoznaczności, co wydaje się kluczowe w dążeniu do ekstrahowania prawidłowych i szerokich wniosków w zakresie geografii handlu. 


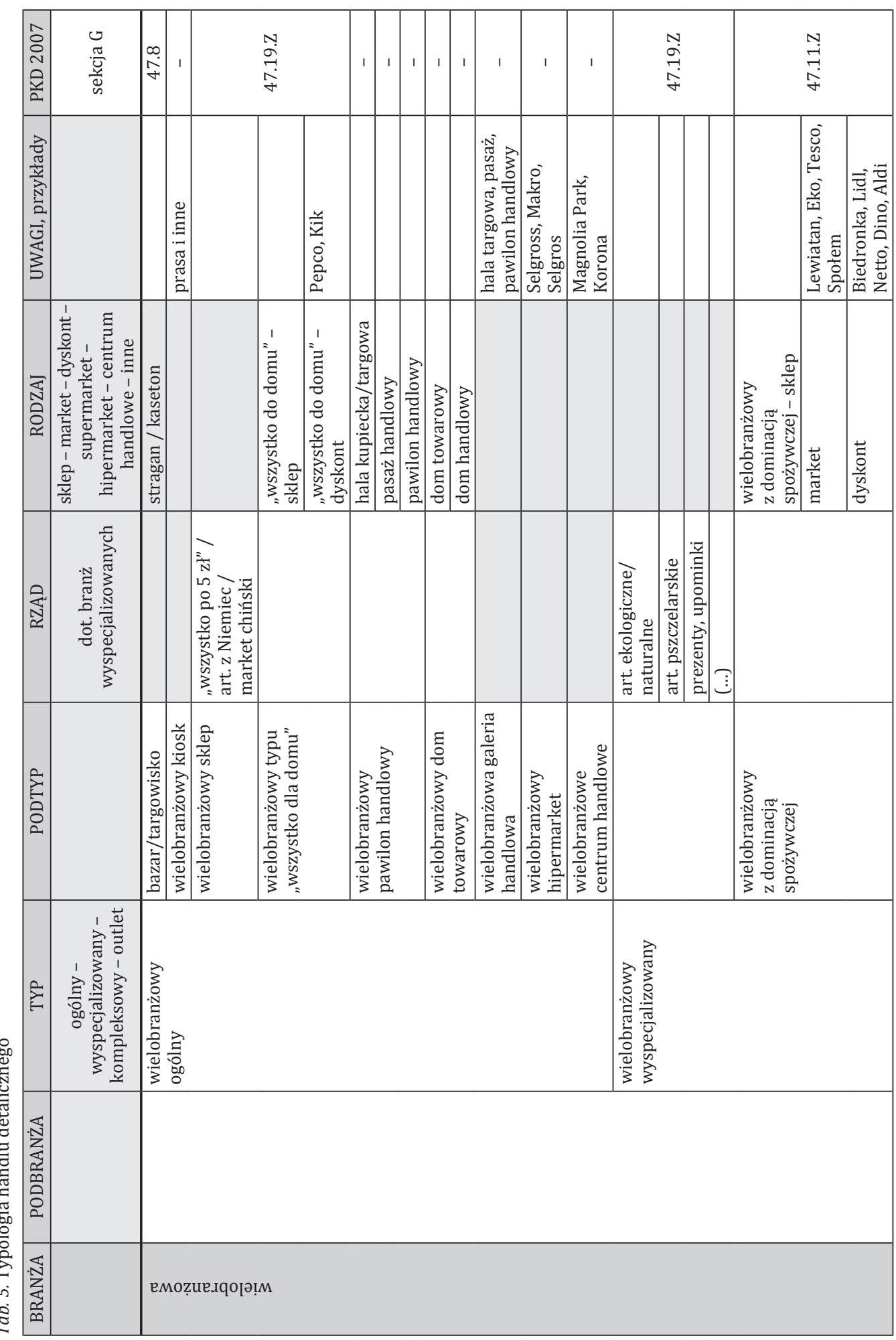




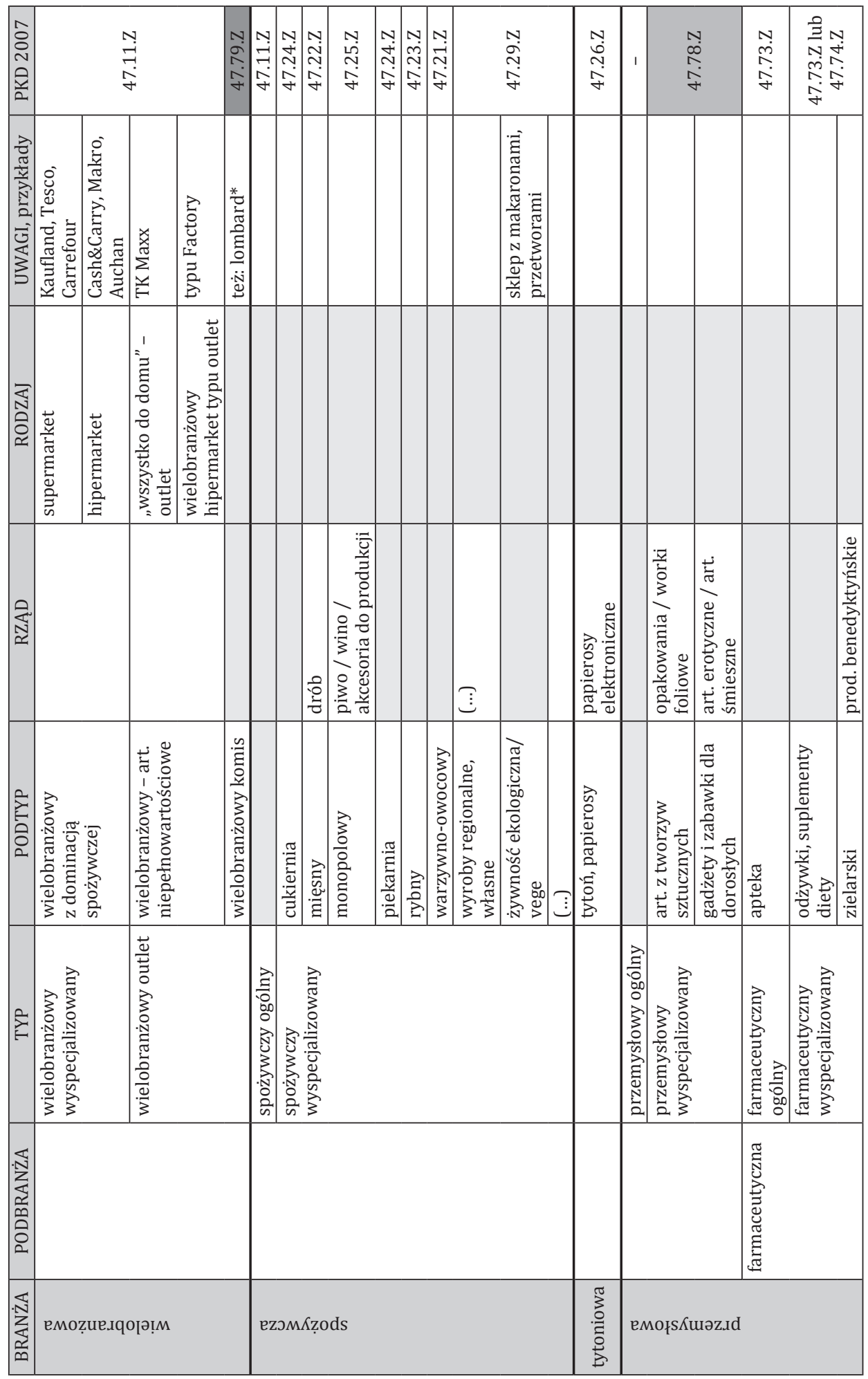




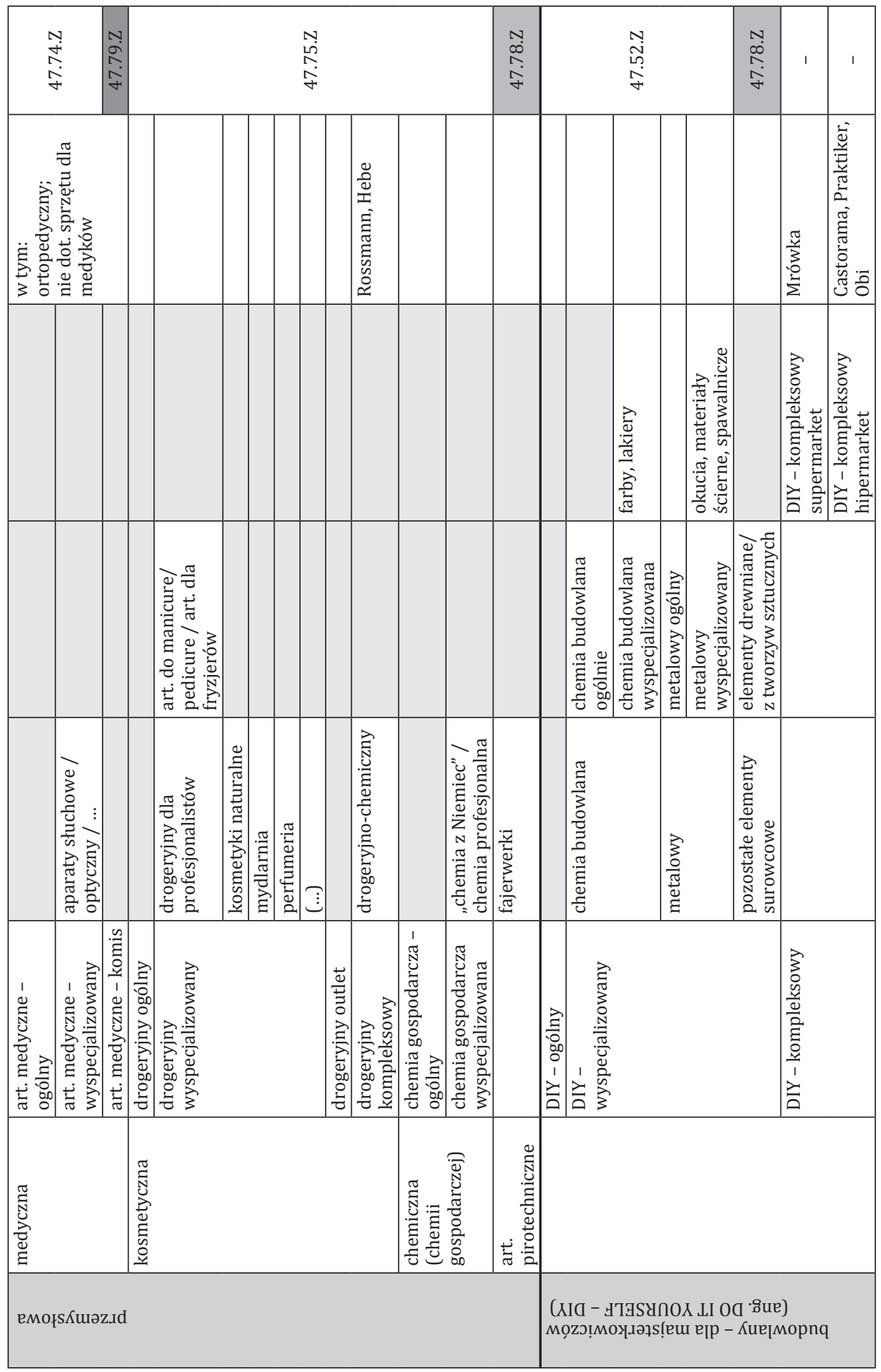




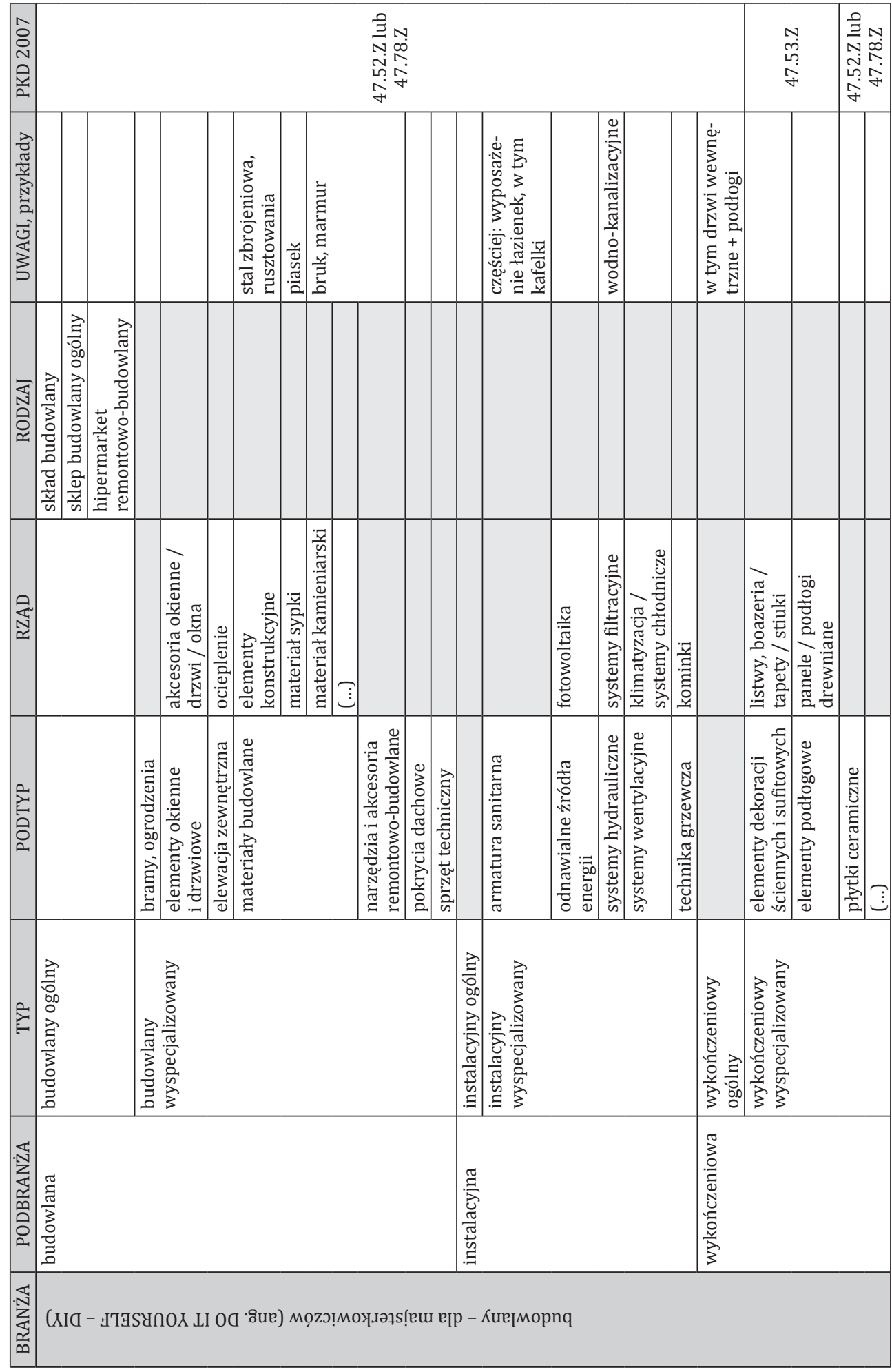




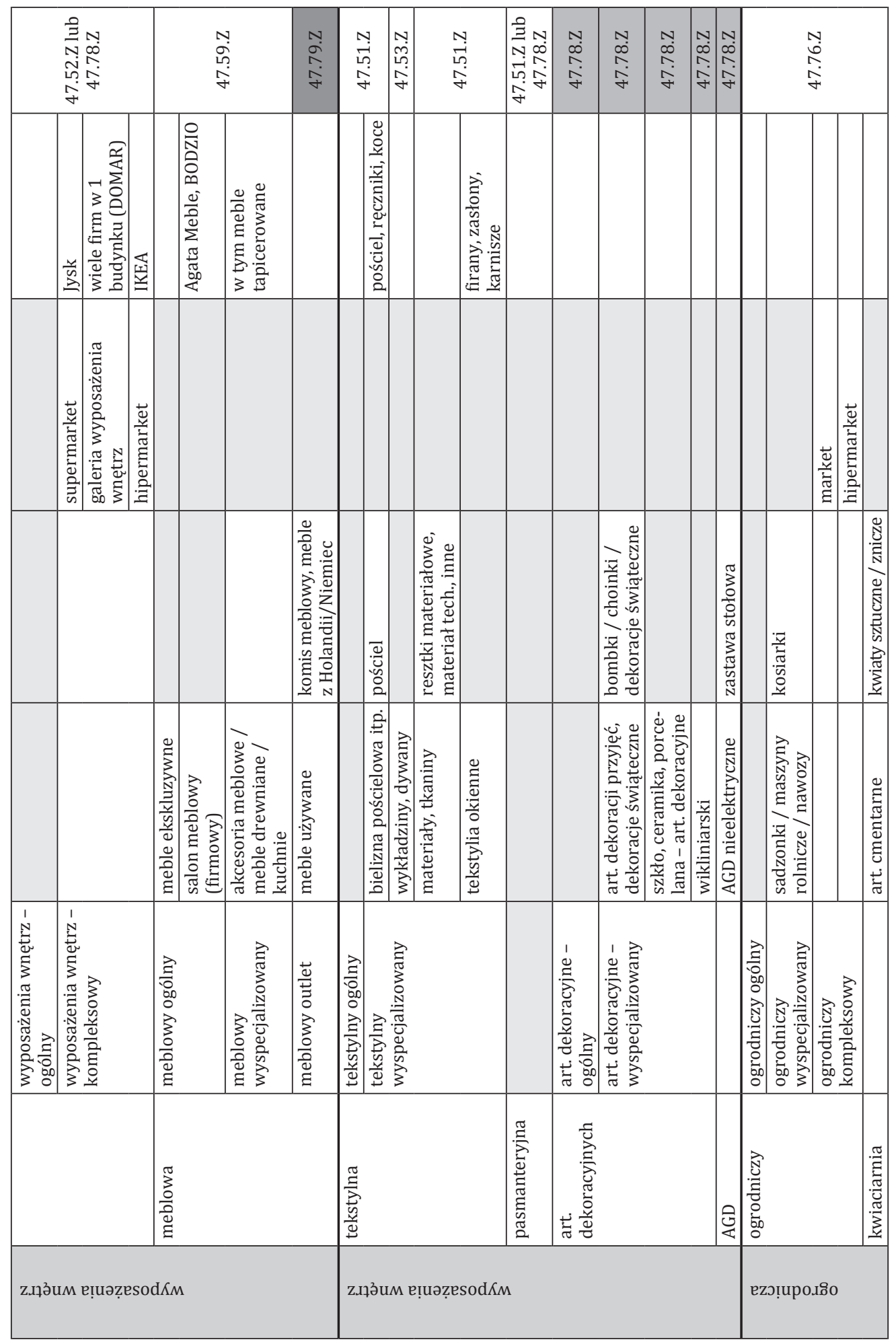




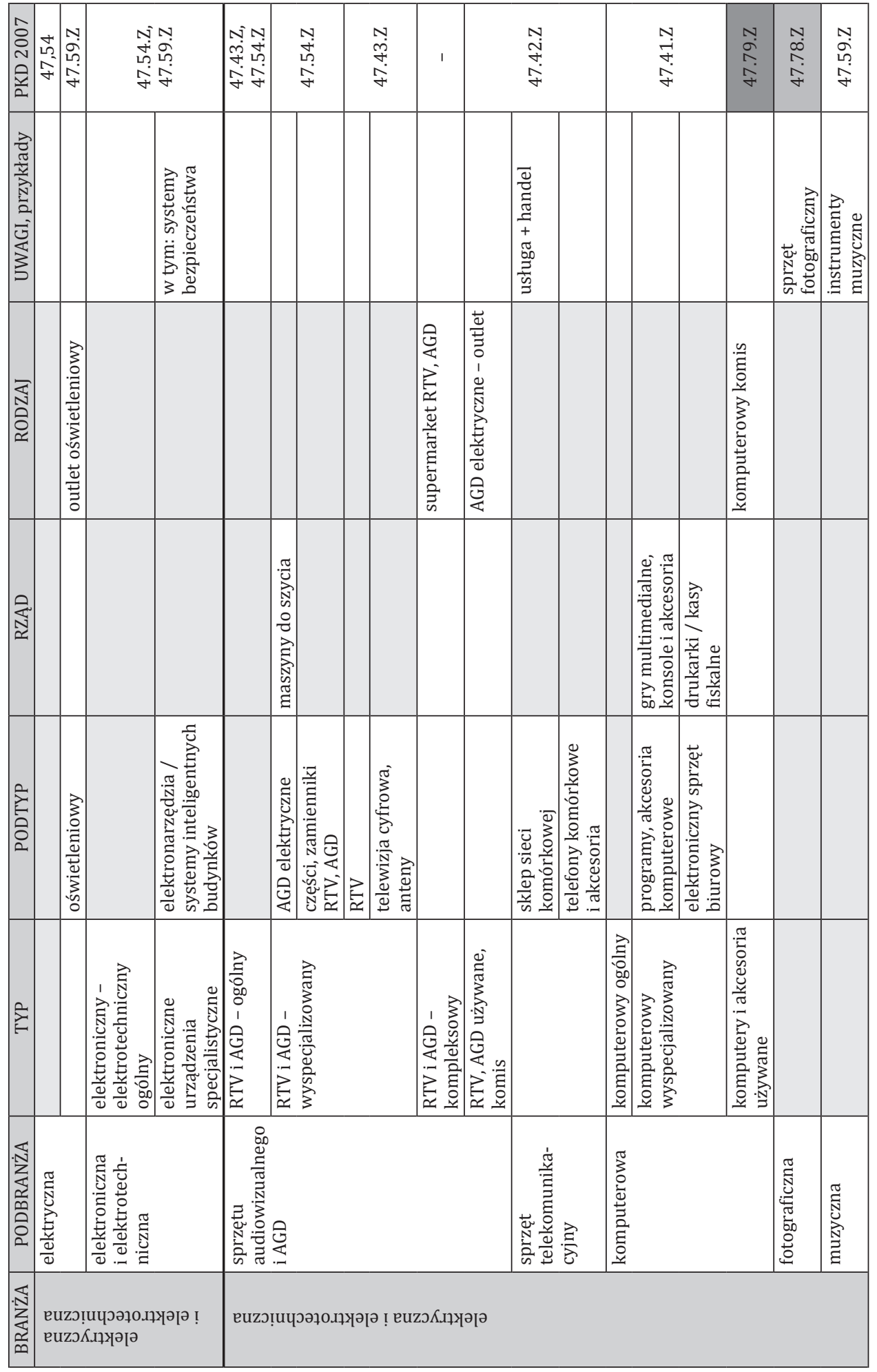




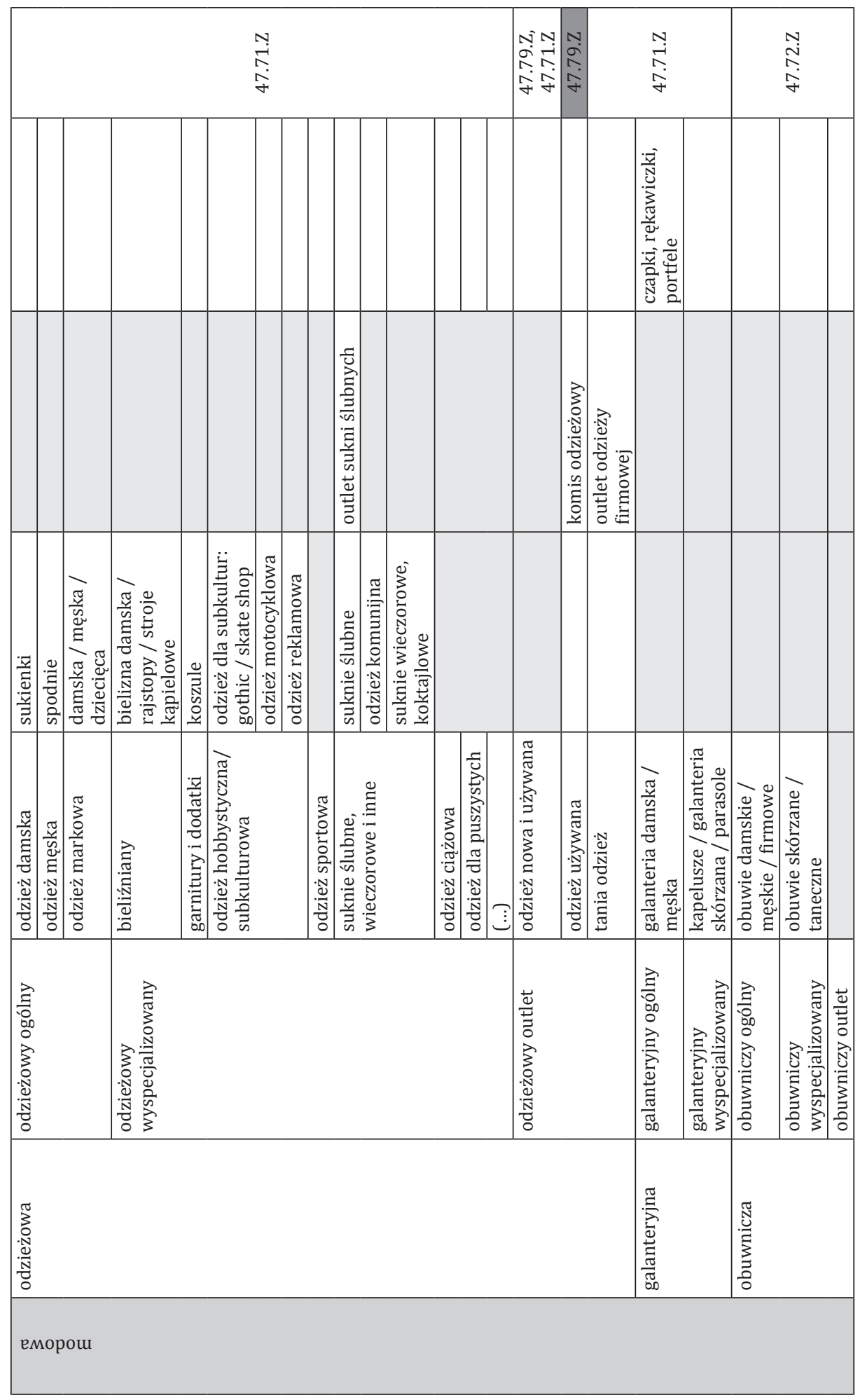




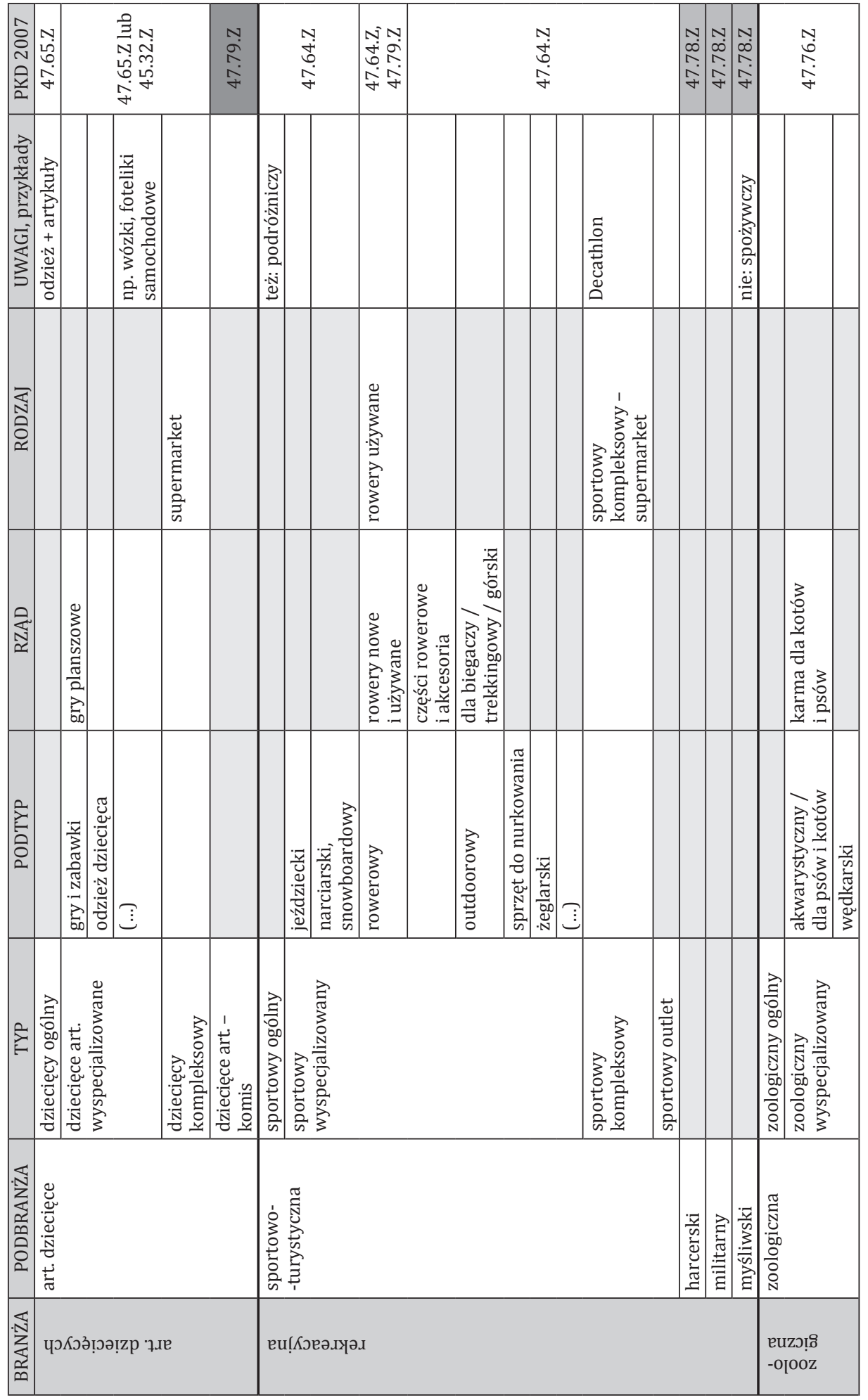




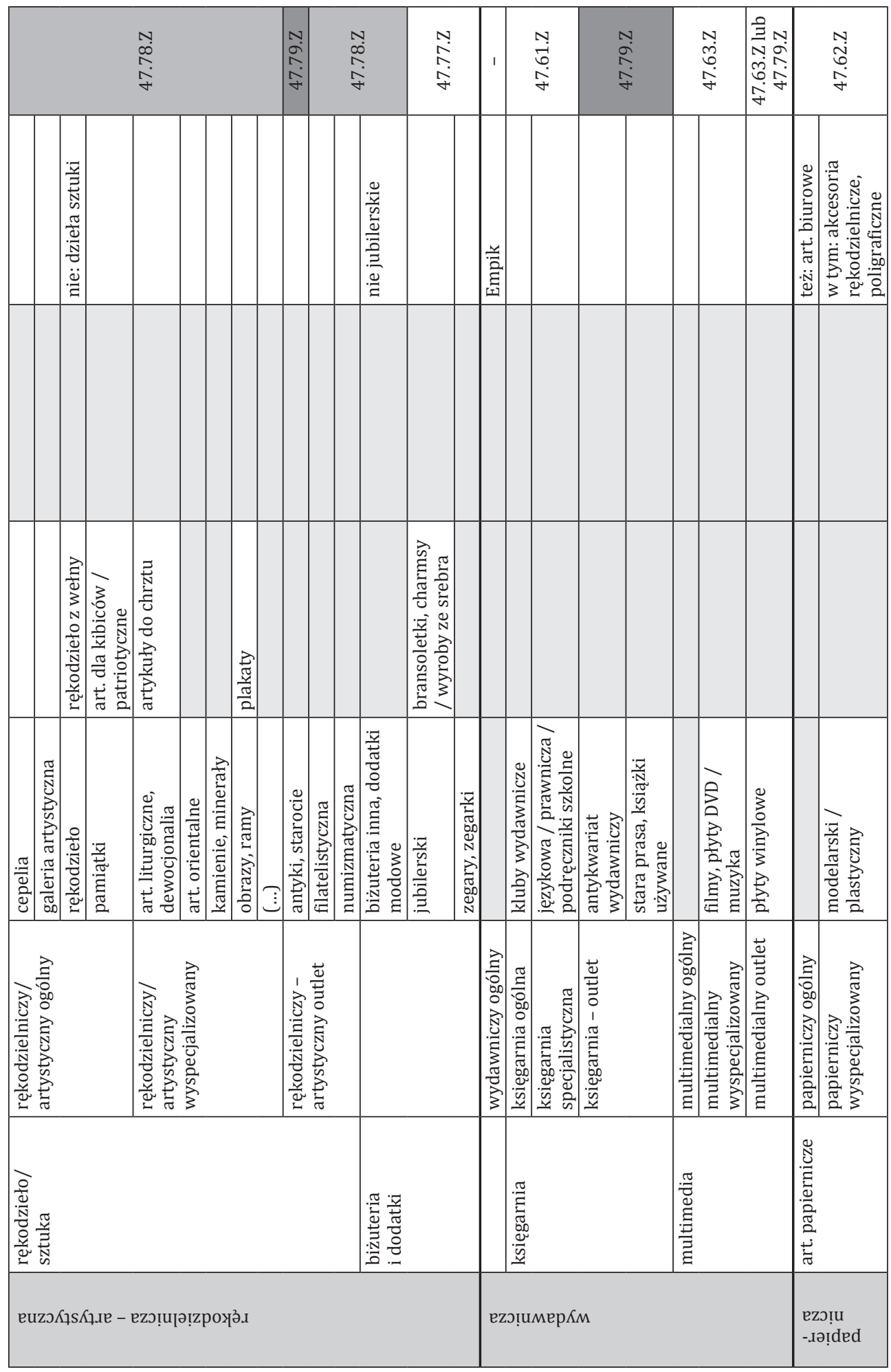




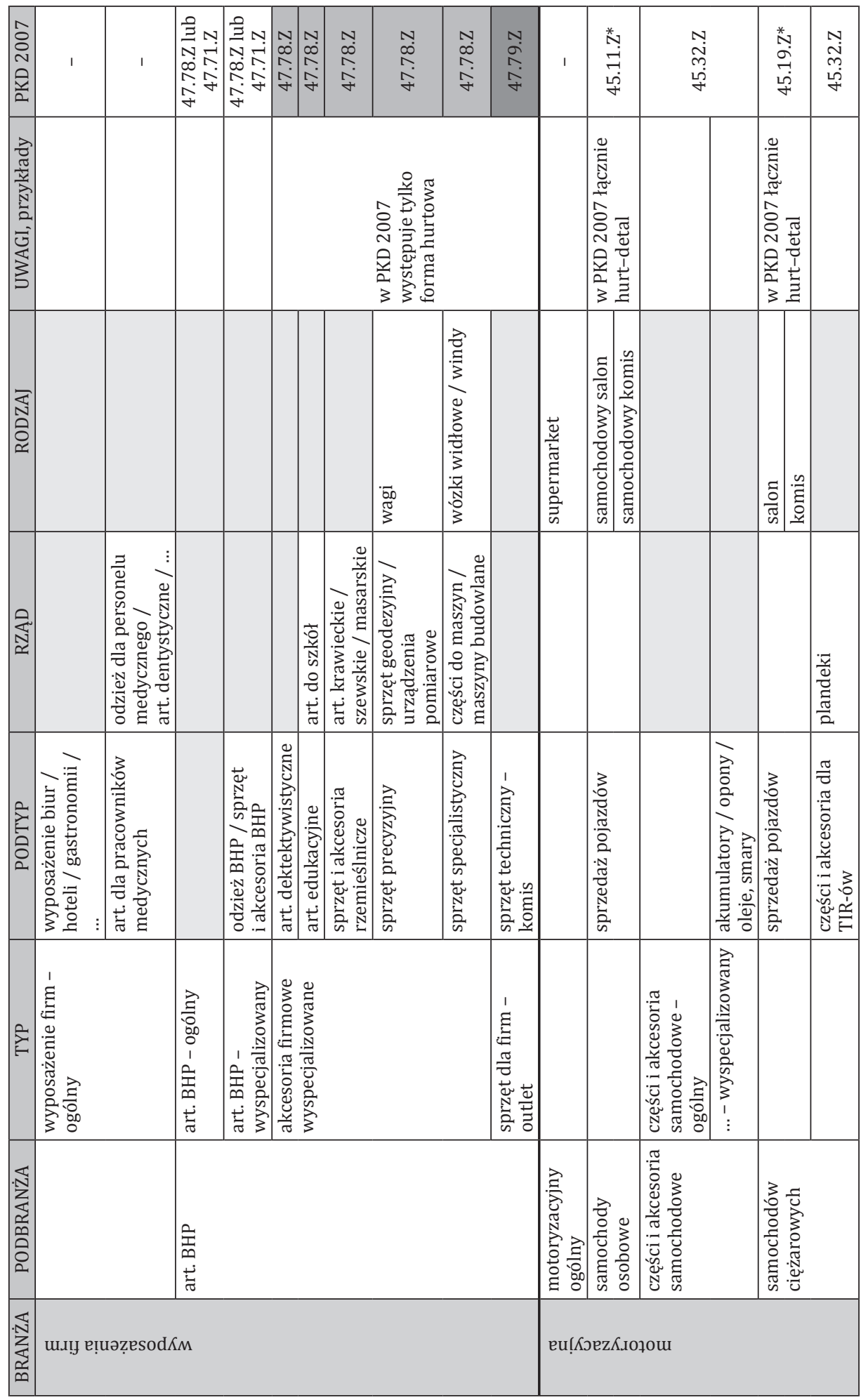




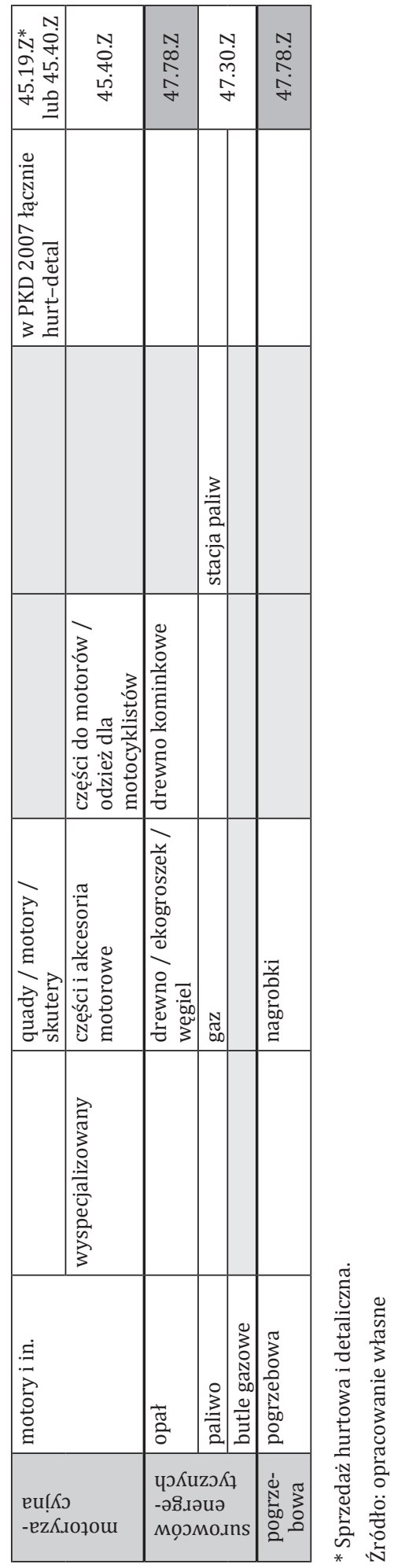




\section{Literatura \\ References}

Berry, B.J.L. (1967). Commercial Structure and Commercial Blight. Research Paper University of Chicago, 85.

Celińska-Janowicz, D. (2016). Rejestry podmiotów jako źródła danych w analizach lokalizacji działalności gospodarczej w mikroskali. Wiadomości Statystyczne, 1(656), 27.

Chudzyńska, I. (1985). Struktura przestrzenna handlu detalicznego w Warszawie. Dokumentacja Geograficzna, 2. Warszawa: Instytut Geografii i Przestrzennego Zagospodarowania Polskiej Akademii Nauk.

Jak uzyskać wpis w rejestrze REGON? (2017, 12 listopada). Gazeta Podatkowa. Pozyskano z https://www.gofin.pl/firma/17,10,305,680,jak-uzyskac-wpis-w-rejestrze-regon.html

Kivell, P.T., Shaw, G. (1980). The Study of Retail Location. W: J.A. Dawson (red.). Retail geography. Routledge library editions: retailing and distribution. London, New York: Routledge Taylor \& Francis Group.

Kucharska, B., Malinowska, M. (2016). Handel detaliczny w Europie. Obszary i wyzwania badawcze. Studia Ekonomiczne. Zeszyty Naukowe Uniwersytetu Ekonomicznego w Katowicach, 270, 143-151.

Maleszyk, E. (1999). Rozwój hipermarketów, supermarketów i sklepów dyskontowych z kapitałem zagranicznym. Wiadomości Statystyczne, 44(6), 44-52.

Maleszyk, E. (2008). Tendencje do specjalizacji handlu detalicznego na rynku artykułów częstego zakupu. Handel Wewnętrzny, 8(54), 1-9.

Miszewska, B., Slenczyk, M. (1998). Stacje benzynowe - nowy (?) element w krajobrazie Wrocławia. Wrocław: Wydawnictwo Uniwersytetu Wrocławskiego, 53-63.

Nowosielska, E. (2000). Sektor usług w aglomeracji warszawskiej 1992-1997: przemiany strukturalne i tendencje rozwojowe. Dokumentacja Geograficzna, 2.

Palomäki, M. (1964). The functional centers and areas of South Bothnia. Finland: Fennia.

Płaziak, M., Szymańska, A. (2016). Uwarunkowania rozwoju handlu i usług na przykładzie Krakowa - Nowej Huty. Przedsiębiorczość Międzynarodowa, 2(1), 231-246.

Prawo telekomunikacyjne (Dz.U. z 2004 r., nr 171, poz. 1800 z późn. zm.).

Pustelnik, R. (1979). Rozmieszczenie miejskich usług handlowych i ich struktura hierarchiczna na przykładzie czterech miast polskich. Wrocław: Politechnika Wrocławska (praca doktorska).

Raczyk, A. (2009). Metody badania przedsiębiorczości oparte na rejestrze podmiotów gospodarki narodowej. W: T. Zioło, T. Rachwał (red.). Rola przedsiębiorczości w kształtowaniu społeczeństwa informacyjnego. Przedsiębiorczość-Edukacja, 5, 133-146.

Rowley, G. (1984). Data Bases and Their Integration for Retail Geography: A British Example. Transactions of the Institute of British Geographers, 9(4), 460-476.

Taylor, Z. (2000). Przekształcenia sieci handlu detalicznego i gastronomii w okresie transformacji społeczno-gospodarczej Polski. Prace Geograficzne, 175.

Twardzik, M. (2009). Zmiany funkcji handlowej małych miast województwa śląskiego. W: T. Marszał (red.). Funkcja usługowa małych miast. Łódź: Wydawnictwo Uniwersytetu Łódzkiego.

Twardzik, M., Halama, A. (2017). Dostępność usług handlowych w obszarach suburbanizacji na przykładzie południowych dzielnic Katowic. Studia Ekonomiczne, 316, 183-196.

Werwicki, A. (2000). Handel targowiskowy aglomeracji łódzkiej na tle jego znaczenia ogólnopolskiego w latach 1994-1997. Łódź: Łódzkie Towarzystwo Naukowe.

Wojdacki, K. (2011). Przestrzenne aspekty rozwoju handlu targowiskowego w Polsce. Handel Wewnętrzny, 6(335), 23-35.

Zallam, I. (1993). Analiza struktury hierarchii zagospodarowania turystycznego i usługowego w obszarach o rozwiniętej funkcji rekreacyjnej. Wrocław: Politechnika Wrocławska (praca doktorska).

Zieliński, A. (2017, 9 października). Rozwój rynku usług telekomunikacyjnych w Polsce po przystqpieniu do Unii Europejskiej. Pozyskano z http://webcache.googleusercontent.com/search? $\mathrm{q}=$ cache:ZkH1CsI8AyYJ:yadda.icm.edu.pl/yadda/element/bwmeta1.element.baztech-article-BAT3-0023-0027/c/httpwww_itl_waw_plczasopismatiti20051-223.pdf+\&cd= $1 \& \mathrm{hl}=\mathrm{pl} \& \mathrm{ct}=\mathrm{clnk} \& \mathrm{gl}=\mathrm{pl}$ 
Zipser, T. (red.) (1977). Wstępne określenie zasad struktury przestrzennej sieci obiektów usługowych. Wrocław: Instytut Architektury i Urbanistyki, Politechnika Wrocławska.

Zipser, T. (red.) (1979). Kompleksowa analiza sieci usług $w$ wybranych rejonach kraju - obszary podgórskie. Wrocław: Instytut Architektury i Urbanistyki, Politechnika Wrocławska.

Zipser, W. (2004). Oddziaływanie wrocławskich hipermarketów na klientów - mieszkańców Dolnego Śląska. W: E. Bagiński (red.). Wybrane wyniki badań nad miejskq sieciq osadniczq Dolnego Śląska. Wrocław: Oficyna Wydawnicza Politechniki Wrocławskiej, 117-126.

Magdalena Mayer-Wydra, mgr inż., doktorantka Politechniki Wrocławskiej, wykładowca Uniwersytetu Wrocławskiego, czynny urbanista, mgr inż. w dziedzinie planowania przestrzennego (Politechnika Wrocławska) oraz mgr w dziedzinie geografii (Uniwersytet Wrocławski). W badaniach zajmuje się problematyką z zakresu struktury usługowej (handlowej) jednostek osadniczych, specyfiką miast poprzemysłowych, jakością przestrzeni publicznych oraz tożsamością miejsca.

Magdalena Mayer-Wydra, M.Sc., Ph.D. student at the Wrocław University of Science and Technology, lecturer at University of Wroclaw, urban planner, M.Sc. title in Urban Planning (Wrocław Univeristy of Science and Technology) and M.Sc. in Geography with specialization in spatial analysis (University of Wroclaw). In her research she deals with problems of service (retail) structure of spatial units, post-industrial cities, quality of public spaces, place identity.

\section{Adres/address:}

Politechnika Wrocławska Wydział Architektury

Katedra Urbanistyki i Procesów Osadniczych ul. B. Prusa 53/55, 50-317 Wrocław, Polska

e-mail: magdalena.mayer@pwr.edu.pl 